\title{
Tieteellinen elämä
}

MILTÄ tuntuisi esittäytyä kansainvälisessä konferenssissa ulkomaisille kollegoille ja kaivaa taskusta esiin käyntikortti, jossa työpaikaksi ilmoitetaan "Helsingin yliopisto, yleisen historian rahanjakoyksikkö"? Tämänkaltaisen kuvan yliopiston organisaatiosta ja sen perimmäisestä luonteesta antaa Helsingin yliopiston suuriin rakenteellisiin uudistuksiin pyrkivien työryhmien raporttien kielenkäyttö. "Rahanjaon periaatteiden kehittämistyöryhmän" tuottamat byrokraattiset selvitykset antavat aiheen pelätä, että hallinto on todella vallannut yliopiston ja tieteelliset käytännöt ovat jääneet kokonaan lapsipuolen asemaan.

Työryhmän tehtäväksi rehtori on antanut yliopiston sisäisen rahanjaon pohtimisen. Rahanjako nähdään osana yliopiston toiminnanohjausta, jonka tavoitteena on yliopiston strategian toteuttaminen mahdollisimman tehokkaasti. Tieteelliset toimijat eli tieteenalayhteisöt saavat tässä ajattelussa tulosyksikön roolin. Tuloksellisuutta puolestaan mitataan mallilla, joka määrittää viime kädessä rahanjaon periaatteet.

Yksinkertaistetusta tuotantotaloudellisesta ajattelusta omaksuttu administratiivismanageriaalinen tulkinta yliopiston toiminnasta antaa aiheen epäillä, että suunnitelmien tekijät eivät itsekään tiedä, mitä yliopistolla tapahtuu. Jos oletamme, että tiedeyhteisön tulisi olla luova yhteisö, emme todellakaan löydä yksimielistä määritelmää tuloksellisuudelle. Yksiköitävissä ja tilastoitavissa oleva tulos on aina manageriaalinen käsite ja tekee väkivaltaa tieteelliselle käytännölle. Tulosyksikkökin näyttää olevan suunnitelmien tekijöiltä hukas- sa. Laitos ja tieteenalat ovat pahasti sekaisin, jos suunnittelijat eivät vielä ole havainneet, että hallinnon rationalisointipyrkimykset ovat saaneet aikaan koko joukon monitieteisiä laitoksia. Nämä ovat yksinomaan hallinnollisia yksiköitä, eivätkä sellaisenaan muodosta toiminnallista tulosyksikköä saati tieteellistä keskusteluyhteisöä.

Kaiken takana on tietenkin nainen. Maggie Thatcher aloitti aikanaan rajut yliopistolaitoksen saneeraukset, ja tauti levisi maailmanlaajuiseksi. Nainen on nyt vain korvautunut mallilla, joka on ottanut arvostelukyvyn ja harkinnan roolin. Entäpä jos rahaa jaettaisiinkin ilman mallia ja harkiten? Mekaanisten periaatteiden sijasta keskustelua olisi mahdollista käydä substanssista ja kysyä, mitä tieteenaloja yliopistolaitoksemme tarvitsee ja paljonko niihin kannattaa panna rahaa. Päätös olisi tietenkin poliittinen, mutta päättäjät eivät ainakaan voisi paeta vastuutaan mallin taakse. Kaikkeen meillä ei tietenkään ole varaa, ja joidenkin tieteenalojen lakkauttaminen olisi kipeä toimenpide. Mallimyllytys vain tuottaa lakkautusuhkia sellaisille tieteenaloille, joita alkeellinenkin harkinta pitäisi suomalaisen yliopiston toiminnan kannalta oleellisina. Sisällöllisten päätösten jälkeen olisi helppo päättää, että minimilaitos (ainelaitos) tarvitse ainakin tietyn kokoisen henkilökunnan ja toiminnalliset edellytykset. Suurempi on enemmän ja sillä siisti. Rahanjako olisi mahdollista suorittaa sisällöllisin, ei mekaanisin perustein. Varsinaisen tiedepoliittisen sisällön katoamista yliopistohallintoa koskevasta keskustelusta voivat kaikki seurata Helsingin yliopiston nettisivuilta osoitteesta http://savotta.helsinki.fi/ kampusrakenne.

MUSTION linnaan kokoontui huhtikuun puolivälissä parikymmentä yhteiskuntatieteellisen teknologiatutkimuksen huippunimeä seminaariin nimeltä "Absent Presence: Localities, Globalities and Method". Suljetun tapahtuman tieteellisinä organisaattoreina olivat John Law, John Urry ja Michel Callon, muiden osallistujien joukossa esimerkiksi Lucy Suchman, Donald Mackenzie, Nigel Thrift ja Rob Shields - siis sekä teknologiatutkimuksessa että brittiläisissä yhteiskuntakeskusteluissa näkyvästi esiintyneitä hahmoja.

Avoin otsikko heijastui siinä, että esitysten aiheet liikkuivat varsin laajalla alalla: mukaan mahtui papereita niin ylikansallisista rahoitusmarkkinoista kuin mobiilin digitaalikulttuurin kansallisista eroista kaukoidässä; niin dualististen metaforien ongelmallisuudesta yhteiskuntatieteen metodologiassa kuin "barokkiajattelusta", joka löytää universaalin yksityiskohdissa; niin kaupungin äänimaailmojen muutoksista kuin geenilaboratorioiden suhteesta sukupuolen määrittämiseen; niin jätteiden kierrosta kulutusyhteiskunnan arkitaloudessa kuin suomalaisen teknologiapolitiikan oletuksesta, jonka mukaan digihuuma siunauksellisuudessaan ja tarpeellisuudessaan koskettaa kaikkia kansalaisia. On odotettavissa, että tasokkaan tapahtuman alustuksista kootaan kirja, huolimatta alustusten keskinäisestä heterogeenisuudesta.

Maininnan arvoista kompromissittoman akateemisessa kokouksessa on, että se oli Nokian kokoonkutsuma ja isännöimä. Kansallisen talou- 
temme kansainvälinen selkäranka oli siis ottanut jonkinlaisen teknologiatutkimuksen mesenaatin roolin: onhan selvää, että paljolti yhteiskuntatieteiden sisään viittaavien ja verrattain abstraktien keskustelujen hyötysovellettavuus ei ole aivan ilmeinen ja suora vaikka toki yhteyksien avaaminen mukaan kutsuttuihin tutkijoihin itsessään lienee yritykselle arvokasta. Kiinnostavaa on, että kun nykyään opetusbyrokraattien puheissa kuulee entistä enemmän vaadittavan yliopistojen tekevän rahoittajien kannalta hyödyllistä tutkimusta ja saavutettujen tulosten nopeaa mitattavuutta, samaan aikaan yksityisellä puolella saatetaan rohkeasti investoida akateemiseen hankkeeseen, jonka epämääräinen mahdollinen hyöty on näkyvissä vasta pitkän ajan päästä, jos sittenkään.

Monia nyt Suomeen seminaarikäynnin tehneitä olisi varmaan mielellään nähty luennoimassa yliopistoissakin. Kokoontuminen eksklusiivisesti intensiivisiin keskusteluihin lienee ollut osallistujille itselleen kuitenkin kevyempi ja miellyttävämpi ratkaisu. Moton Connecting people sisäänrakennettu kaksinaisuus tuli siis konkreettisesti esiin: kyky valita globaalisti entistä paremmin kenen nimenomaisen kanssa ollaan tekemisissä merkitsee samalla, että kaikkien kanssa ei ehditä olla tekemisissä...

PIERRE Bourdieun kuolemasta ei ehtinyt kulua kuin hetki, kun jo alkoi Bourdieu-kirjallisuuden tulva. Bourdieun oma tuotteliaisuus oli omaa luokkaansa, ja se jatkuu vielä haudan takaa. Ensiksi ilmestyi Bourdieun ns. poliittisten kirjoitusten kokoelma Interventions politiques 1964-2000
(Agone), lähes 500-sivuinen tiiliskivi; sitten pieni kirjanen tv-haastattelusarjasta Antoine Spiren kanssa (Éditions de l'Aube). Nyt on julkaistu myös Bourdieun - viimeinen?! - teos Le Bal des célibataires: Crise de la société paysanne en Béarn (Seuil), jonka hän ehti viimeistellä ennen sairastumistaan. Se käsittää kolme artikkelia, joissa tarkastellaan eri kannoilta poikamiesten elämää talonpoikaisyhteisössä Bearnissa, Bourdieun synnyinseudulla. Tekeillä on myös bibliografia Bourdieun tuotannosta, joka käsittää yli 45 kirjaa ja 500 artikkelia. Varsinainen Bourdieu-kirjallisuusbuumi lienee vasta tulossa. Keväällä on jo ilmestynyt pari opusta: Suomessa vähän tunnetun originellin filosofin Michel Onfrayn Célébration $d u$ génie colérique: Tombeau de Pierre Bourdieu (Galilée) sekä aiemminkin Bourdieun ajattelusta julkaisseen Patrice Bonnewitzin Pierre Bourdieu: Vie, oeuvres, concepts (Ellipses).

ANTHONY Giddens luennoi London School of Economicsin (LSE) rehtorina vuosittain luentosarjan Director's Lectures, joka on - sanomattakin selvää - hyvin suosittu tapahtuma. Hänellä on ollut tapana myös julkaista luentonsa LSE:n verkkosivulla, joten niihin voi tutustua etäältäkin. Nyt verkossa ovat hänen lukuvuoden 2001-2002 luentonsa. Yleisotsikkona oli Global Futures at a Time of Transition, jonka alla Giddens tarkastelee tuttuun tyyliinsä muun muassa maailmanyhteiskuntaa sekä kansallisvaltion ja perheen tulevaisuutta. Giddensin tuntien luennoista ilmestynee aikanaan myös kirja, mutta ne ovat siis jo nyt uteliaiden luettavissa.
LEHTEMME ensimmäinen toimitussihteeri (vuodelta 1976) on saanut 50-vuotisjuhlakirjansa. Prof., KTT Raimo Loviolle luovutettiin hänen juhlakirjansa Helsingin Kauppakorkean Johtaminen ja organisaatiot -laitoksen tiloissa 8. toukokuuta. Kirjan nimi on Tutkijan elämän värit (Kustannus Oy Taifuuni) ja siinä kirjoittaa 27 tutkijaa ja ystävää. Kirjaa sitoo yhteen hieno idea Raimo Lovion elämän värikausista, joille eri kirjoittajat sijoittuvat: 70-luvun punainen kausi, 80-luvun sininen kausi, 90-luvun vihreä kausi ja nykyinen keltainen kausi. Luovutustilaisuudessa läsnäolijoita kiihotti kysymys keltaisesta kaudesta ja sen perusteista, koska värit oli kirjan koonnut ystäväpiiri kuullut Raimolta itseltään. Kiitos- ja vastauspuheessaan juhlinnan kohde esittikin keltaisen olevan hänen oma värinsä - vuoden -68 sadetakin keltaisuudesta pöytälaatikon rakkausrunojen keltaiseen paperiin asti. Sitten tuo 50-vuotias kiteytti koko värimetaforiikan sanomalla, että oli tuntenut olleensa aina jonkin värin palveluksessa: ensin punaisen, sitten sinisen ja vihreän. Ja nyt keltaisella kaudellaan hän ei ole kenenkään palveluksessa vaan tekemässä itseään omaksi itsekseen. Onnittelemme ja odotamme Raikalta keltaisen kauden juttua lehteemmme!

OLIKO Otto Ville Kuusinen perestroikan varhainen edelläkävijä? Kuusinen ehdotti 1950-luvulla, että Neuvostoliiton kommunistinen puolue luopuisi proletariaatin diktatuurin tunnuksestaan. Kuusisen johdonmukaisen argumentaation mukaan tunnus oli muuttunut tarpeettomaksi. Olihan Neuvostoliitto nyt luo- 
katon yhteiskunta, jossa työväenluokka oli vallassa. Ketä vastaan siis tuota rautaista diktatuuria enää tarvittaisiin? Kuusinen, joka tunsi Leninin teokset perin pohjin, osasi myös esittää kantansa tueksi suuren joukon osuvia Lenin-sitaatteja. Ehdotus, jolle tiettävästi oli hankittu jo etukäteen Nikita Hrushtshevin kannatus, suututti ainakin perin pohin Suomessakin hyvin tunnetun kulttuuriministeri Furtsevan. Kuten tunnettua, NKP ei kuitenkaan hennonnut tuosta rakkaasta tunnuksestaan tuolloin eikä myöhemminkään luopua. Kyseessä ei suinkaan ollut vain teoreettinen puolueen sisäinen kädenvääntö, vaan Kuusisen välienselvittely stalinismin kanssa, jonka poliittisen terrorin proletariaatin diktatuuri oli oikeuttanut.

Tämän yllättävän, Kuusisen politiikon ja teoreetikon kuvaa oleellisesti rikastuttavan tiedon kertoi moskovalainen historioitsija Sergey Zhuravlev Helsingin yliopiston Renvall-instituutissa pitämässään esitelmässä. Zhuravlev on Timo Vihavaisen aloitteesta penkonut Moskovan arkistoja ja löytänyt sieltä monia yllättäviäkin Otto Ville Kuusisen persoonaa ja uraa koskevia tietoja. Kuusisen virallinen rooli monien tärkeiden valtiollisten ja puoluetehtävien hoidossa on toki ollut varsin hyvin tiedossa. Vähemmän tunnettua on se, että Kuusinen ei ollut vain kulloisen- kin puoluejohdon käytettävissä oleva tahdoton työkassara, vaan hän näytteli ainakin 1950luvun lopulla varsin tärkeää roolia puolueen johtavana teoreetikkona, Nikita Hrushtshevin luottomiehenä ja eräänlaisena teoreettisena neuvonantajana tai takapiruna. Se, että juuri Kuusinen sai puolueelta tehtäväkseen toimittaa Marxismin-leninismin perusteet -teoksen, ei ollut siten myöskään vain muodollisuus.

Teoksen oli tarkoitus korvata aikaisemmat Stalinin kauden perusoppikirjat, jotka olivat nyt käyneet käyttökelvottomiksi. Kuusinen kokosi ympärilleen toimituskunnan, joka koostui nuorista tutkijoista ja yliopistomiehistä. Monet näistä Kuusisen "pojista" nousivat sittemmin johtavaan asemaan Breznevin aikaisessa puoluehierarkiassa ja neuvostoakatemiassa. Kuusinen kirjoitti itse teoksen alku- ja loppuluvun sekä kommentoi perusteellisesti jokaisen avustajansa kirjoituksia. Monessa suhteessa teoksessa näkyy siis Otto Villen kynänjälki. Kuusisen aloitteesta teoksen toimituttamista ohjasi varsin tuore ajatus: marxismi-leninismiin tuli suhtautua luovasti eikä kuolleena kirjaimena. Klassikkojen oppeja tuli arvioida nykypäivän ongelmien valossa ja pohtia sitä, mikä niissä on kestävää suhteessa yhteiskunnan viimeaikaiseen kehitykseen. Niinpä Kuusinen piti naurettavina ja poliittisesti haitallisina väitteitä työväenluokan aseman jatkuvasta kurjistumisesta kapitalismissa. Jokainen työläinenhän saattoi itse todeta ne virheellisiksi.

Kuusisen luovan teoreetikon uran huippuvuodet ajoittuivat muutamaan vuoteen ennen hänen kuolemaansa 1950luvun lopulla. Hän ei tyytynyt kommentoimaan ja neuvomaan - eräänlaisena näkymättömänä harmaana eminenssinä - puolueen pääsihteeriä vain keskeisissä marxismileninismin kysymyksissä. Kun Hrushtshev Amerikan matkaltaan palattuaan kertoi innoissaan, että jokaisella amerikkalaisella työläisellä on oma auto - "Meidänkin pitää ryhtyä valmistamaan autoja kaikille!" -, Kuusinen esitti varovaisia epäilyjä sekä hankkeen realistisuudesta että järkevydestä ja ehdotti sen sijaan kehitettäväksi autovuokraamoita, joista neuvostotyöläiset voisivat vuokrata auton vaikkapa viikonlopun dacha-retkelle. Samassa yhteydessä Kuusinen ehdotti kerrostaloihin avattavaksi yhteisiä koneistettuja pesutupia, jottei jokaisen työläisvaimon tarvitsisi turhaan hankkia omaa pesukonettaan, joka seisoisi kuitenkin suurimman osan päivää käyttämättömänä. - Lieneekö Otto Villen kollektivistinen kulutusideaali sittenkin peräisin suomalaisten kerrostalojen pesutuvista? 